\begin{tabular}{|c|c|}
\hline & $\begin{array}{r}\text { ABSYARA: Jurnal Pengabdian Pada Masyarakat } \\
\text { Vol. 1, No. 2, Desember } 2020 \\
\text { Hal. } 70-79\end{array}$ \\
\hline 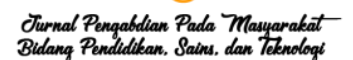 & e-ISSN: 2723-6269 \\
\hline
\end{tabular}

\title{
Pendampingan public speaking pada tutor lembaga kursus bahasa Inggris
}

\author{
ST. Ayu Surayya*1, Maman Asrobi², Ary Prasetyaningrum ${ }^{3}$ \\ 1*andreasurayya@gmail.com \\ 1,2,3 Bahasa Inggris, Universitas Hamzanwadi
}

Received: 12 November 2020 Accepted: 24 Desember 2020 Online Published: 31 Desember 2020

DOI: 10.29408/ab.v1i2.2724 URL: http://dx.doi.org/10.29408/ab.v1i2.2724

\begin{abstract}
Abstrak: Berdasarkan temuan dilapangan, ternyata masih banyak lulusan dari lembaga kursus yang masih belum mengerti teknik public speaking. Padahal lembaga kursus tersebut termasuk lembaga kursus terkenal di Indonesia. Para lulusan ini memang relatif terhitung cepat dalam praktik membaca maupun berbicara dengan menggunakan Bahasa Inggris. Namun, lancarnya produksi kata ini tidak diimbangi dengan variasi suara, perubahan intonasi dan minim makna. Sebagai dosen jurusan Bahasa Inggris, tentu hal ini juga menjadi tanggung jawab bersama. Terlebih, para lulusan ini kini telah berdikari membuka lembaga kursus Bahasa Inggris sendiri. Sehingga dituntut untuk dapat berkomunikasi kepada peserta didiknya. Dengan demikian, sangat diharapkan bahwa lembaga kursus yang sekarang sudah berdiri, khususnya di kecamatan Selong, dapat meningkatkan kualitas pembelajaran dengan menerapkan teknik public speaking yang benar. Oleh sebab itu perlu diadakan pelatihan public speaking pada tutor lembaga kursus bahasa inggris Adapun rancangan pengabdian yang dilaksanakan adalah: 1.) Penyampaian materi pendampingan, 2.) Pelaksanaan praktik berbicara di intern forum, 3.) Study tour pada lembaga kursus lain, 4.) Pelaksanaan praktik berbicara sekaligus evaluasi di luar forum. Pengabdian pada masyarakat ini mendapatkan hasil yaitu pemahaman para tutor lembaga kursus Bahasa Inggris yang ternaung dalam Foreign Language Center (FLC) kecamatan Selong, Lombok Timur telah meningkat dilihat dari bagaimana mereka menerapkan teknik public speaking saat praktik mengajar sebagai tutor Bahasa Inggris.
\end{abstract}

Kata kunci: Bahasa Inggris; Lembaga Kursus; Public Speaking

\begin{abstract}
Based on the observations' results, many graduate students from an English course institution still do not understand public speaking techniques. Even though the course institution is a well-known course institution in Indonesia, these graduates are relatively fast reading and speaking English. However, this word's smooth production was not matched with variations in voice, changes in intonation, and minimal meaning. As a lecturer in the English department, this is also our responsibility. Moreover, these graduates are now having their English course institutions independently. They are required to be able to communicate with their students. It is hoped that the current course institutions, especially in the Selong sub-district, can improve the quality of learning by applying correct public speaking techniques. Therefore, it is necessary to hold public speaking training for tutors at English language course institutions. The service plans carried out are: 1.) Delivery of mentoring material, 2.) Implementation of speaking practice in internal forums, 3.) Study tours at other course institutions, 4. ) Practicing speaking as well as evaluating outside the forum. This community service has increased English tutors' understanding in the Foreign Language Center (FLC) of Selong sub-district, East Lombok, seen from how they apply public speaking techniques during their teaching practice English tutors.
\end{abstract}

Keyword: English Course Institute; English Language; Public Speaking

\section{PENDAHULUAN}

Pada dasarnya, public speaking adalah presentasi yang diberikan langsung kepada banyak audiensi. Tujuan untuk berbicara di depan umum ini bisa untuk mendidik, menghibur atau mempengaruhi pendengar. Artinya, target utama dan krusial dalam praktik public speaking adalah perhatian dari pendengar (Maclntyr, 2007). Namun, berbeda dengan presentasi secara 
online yang sering terdiri dari slide dan pre-recorded video, public speaking lebih menekankan pada ujaran yang langsung diucapkan pada saat itu juga. Jadi, berdasarkan fungsi dan karakteristik public speaking tersebut, bidang ini banyak ditemukan dalam event formal dan informal dengan banyak audiensi, seperti seminar, presentasi, pidato, diskusi panel, rapat pleno, drama, kampanye, mengajar di kelas dan sebagainya (Andriyanti, 2015; Putri, 2017).

Sebenarnya, kesadaran akan pentingnya public speaking sendiri telah dikenali dalam peradaban manusia sejak berabad-abad lampau. Sejarah mencatat bahwa kegiatan public speaking telah dilakukan di Yunani dan Romawi Kuno dalam bentuk retorika (Burhanuddin, 2019). Namun, pada kenyataannya, hanya beberapa bidang pendidikan, seperti ilmu komunikasi, ilmu politik, penceramah agama yang fokus menempatkan public speaking sebagai bidang yang harus dipelajari. Hal ini terlihat dari banyaknya penelitian ilmiah yang ramai membahas tentang public speaking pada bidang ilmu agama, sosial dan politik (Munip 2016; Burhanudin \& Syathori, 2019; Yanti, 2017; Syahroni, 2019). Padahal, selain bidang tersebut, seorang pendidik formal maupun informal pun sangat membutuhkan keterampilan berbicara.

Dosen, guru, maupun tutor sebuah lembaga kursus pun membutuhkan keterampilan berbicara yang baik. Keterampilan ini mampu melatih kepercayaan diri mereka untuk berkomunikasi (berbicara) dengan peserta didik secara efektif dengan penggunaan kata kata yang jelas, tepat dan menarik (Syahroni, 2019). Jadi bisa dikatakan, para pendidik ini tidak hanya dituntut untuk memiliki pengetahuan pedagogis dan konten saja. Selain itu, mereka juga harus mampu menyampaikan ide dan pengetahuan yang mereka miliki Arsjad \& Mukti (1988: 23) dengan memperhatikan beberapa teknik public speaking, seperti artikulasi, intonasi, gerak tubuh, kontak mata, dan lain-lain (Ahmad, 1990:18).

Pengaruh penggunaan teknik public speaking bagi pendidik ini sangatlah besar. Pendidik yang memiliki keterampilan berbicara yang baik tentu akan dianggap memiliki kelebihan, keunggulan maupun keahlian dibidang apapun (Pratiwi, dkk., 2006) karena bahasa seseorang itu mencerminkan pikirannya (Tarigan, 1988: 1). Sebaliknya, pengajaran yang kurang hidup dan tidak ada interaksi yang menarik akan dihadapi oleh pendidik yang tidak memiliki keterampilan berbicara. Karena keterampilan public speaking milik semua warga masyarakat (Sirait, 2008: 3) dan juga bisa dilatih (Nugrahani, dkk., 2019), maka para pendidik seharusnya mendapat bekal dan pendampingan yang cukup terkait ilmu ini.

Salah satu pendidik yang juga perlu mempelajari teknik public speaking adalah para anggota Foreign Language Center (FLC). Forum ini didirikan secara mandiri pada awal tahun 2020 oleh para mahasiswa Universitas Hamzanwadi. Para anggota dari forum ini adalah lulusan dari beberapa lembaga kursus di dalam wilayah Lombok, maupun luar Lombok dan kini aktif dalam organisasi English Speaking atau pun menjadi tutor di lembaga kursus Bahasa Inggris. Selain mengagendakan pendampingan berbahasa Inggris secara intents, forum ini juga secara aktif mengadakan penyuluhan kepada masyarakat bertema umum, seperti penyuluhan tanaman hidroponik, pendampingan penulisan ilmiah, dan lain-lain. Dapat dikatakan bahwa agenda yang forum ini laksanakan memang sangat membutuhkan keterampilan berbicara yang baik.

Setelah melakukan observasi dan interview, tim PKM dosen program studi Bahasa Inggris Universitas Hamzanwadi menemukan beberapa masalah yang dihadapi oleh anggota forum ini. Berdasarkan hasil observasi, beberapa dari anggota ini memiliki mental yang kuat sebagai pengajar dengan pengetahuan bahasa Inggris yang baik. Namun, sayangnya tidak 
menerapkan teknik public speaking, seperti mengajar secara pasif, terlalu cepat berbicara, tidak menggunakan permainan intonasi, artikulasi, dan cenderung kurang interaktif. Sedangkan dari hasil interview, sebagian dari anggota forum mengaku masih malu untuk berbicara di depan publik. Masalah inilah yang menjadikan hanya satu atau dua orang saja yang aktif berbicara di depan masyarakat.

Pengabdian pendampingan teknik public speaking ini bertujuan untuk meningkatkan pengetahuan para tutor lembaga kursus Bahasa Inggris yang bernaung dalam Foreign Language Center (FLC) di kecamatan Selong, kab. Lombok Timur - NTB. Dengan pemberian edukasi kepada para tutor, diharapkan edukasi teknik public speaking ini juga akan diteruskan kepada peserta lembaga kursus mereka yang lain. Selain itu, pendampingan ini juga berfungsi untuk meningkatkan kualitas lembaga kursus yang mereka pegang karena memiliki tutor yang cakap, menarik, interaktif dan mudah dimengerti. Kepribadian inilah yang ingin dibentuk selama kegiatan pendampingan sehingga pembelajaran yang para tutor laksanakan dapat berlangsung secara efektif dan menarik di depan umum. Dengan demikian, untuk meningkatkan kualitas tutor lembaga kursus Bahasa Inggris kecamatan Selong kabupaten Lombok Timur-NTB maka perlu adanya pendampingan public speaking.

\section{METODE PELAKSANAAN}

\section{Waktu dan tempat}

Pelaksanaan kegiatan ini dilaksanakan pada bulan Oktober 2020 yang dilaksanakan sebanyak 5 kali pertemuan. Pertimbangan dalam pemilihan bulan ini sebagai masa pengabdian karena bulan ini telah diberlakukan PSBB. Artinya, para dosen dan peserta pendampingan sudah mendapat izin untuk terjun langsung ke lapangan dan melakukan pengabdian dengan tetap menerapkan protokol kesehatan.

Kelompok yang menjadi target utama pelaksanan program ini adalah para tutor lembaga kursus bahasa Inggris sebanyak 15 orang yang bernaung dalam komunitas bahasa bernama Foreign Language Center (FLC) di kec. Selong, kab. Lombok Timur. Pemilihan komunitas ini berdasarkan pertimbangan bahwa para tutor akan kembali ke lembaga kursus mereka masingmasing, sehingga pengetahuan dan pemahaman tentang teknik public peaking akan teruskan pada peserta lembaga kursus mereka masing-masing.

\section{Prosedur pelaksanaan}

Kegiatan pendampingan public speaking dengan teknik dan materi (artikulasi, chunking dan pausing teknik, rythm, retoris, interaksi atau timbal balik, gestur tubuh serta kontak mata) merupakan komponen utama dalam penguasaan audience saat berbicara di depan umum. Selain itu, pendampingan ini berfungsi untuk meningkatkan kualitas diri tutor sekaligus kualitas lembaga kursus yang mereka pegang. Kegiatan pendampingan ini merupakan program pengabdian kepada masyarakat (PKM) dengan tahapan kegiatan dimulai dengan survey tempat, proses perizinan, penyusunan materi edukasi dan persiapan media latihan, dan pencarian koneksi untuk proses pendampingan. Kegiatan yang utama adalah pemberian materi mengenai pentingnya public speaking dan teknik public speaking, disusul dengan pendampingan intern forum dan ekstern forum. Berdasarkan keterampilan public speaking yang termasuk dalam performance assessment, maka evaluasi akhir dalam bentuk observasi dan penilaian skala rubrik. Dalam pelaksanaannya, program ini akan dilaksanakan dalam beberapa kegiatan, yaitu: 
1. Penentuan lokasi

Kegiatan ini dilaksanakan di kota Selong, kec. Selong, kab. Lombok Timur. Kota ini dianggap cocok dalam pelaksanaan kegiatan karena kota ini merupakan pusat pendidikan formal dan informal di kabupaten Lombok Timur. Terlebih, FLC yang merupakan mitra juga terletak di kota Selong. Para anggota yang tergabung dalam FLC merupakan pengajar dan mahasiswa yang berasal dari berbagai daerah di pulau Lombok. Dengan pelaksanaan di pusat bahasa, tentunya para anggota akan menyebarkan ilmu dan pengalaman pendampingan mereka ketika kembali ke daerah masing-masing.

2. Koordinasi dengan mitra kegiatan

Dalam tahapan ini, peneliti berkoordinasi dengan pihak Foreign Language Center (FLC) selaku mitra untuk membahasas proses organisasi pelaksanaan kegiatan, mulai dari mengkoordinasi waktu pelaksanaan, skema acara, mengumpulkan peserta, sampai dengan penyediaan sarana dan prasarana kegiatan.

3. Pendampingan

Pada waktu yang telah ditentukan, tim pelatih dan pembimbing memberikan penyampaian materi tentangpentingnya mempelajari dan melatih kemampuan berbicara untuk meningkatkan kualitas diri dan lembaga kursus. Beberapa teknik untuk menghindari kecemasan berbicara (anxiety) dengan pengelolaan emosi dan teknik pengelolaan audience juga disampaikan pada saat sosialisai ini. Dalam proses ini, tim menghadirkan nara sumber dari rekan dosen yang memiliki pemahaman dalam teknik public speaking dan pengalaman di bidang public speaking, seperti berpengalaman menjadi pemateri dan berpengalaman dalam debat berbahasa Inggris.

Adapun ruang lingkup dan capaian pada pendampingan ini adalah sebagai berikut:

Tabel 1. Ruang lingkup program dan target sasaran

\begin{tabular}{|c|c|c|}
\hline Jenis kegiatan & Sasaran & Target Capaian Kegiatan \\
\hline $\begin{array}{l}\text { Penyampaian materi public } \\
\text { speaking (daring dan } \\
\text { offline) }\end{array}$ & $\begin{array}{l}\text { Peserta Language Center } \\
\text { Forum (LCF) }\end{array}$ & $\begin{array}{l}\text { Peserta mengerti teknik } \\
\text { berbicara dan membaca yang } \\
\text { menyenangkan, mudah } \\
\text { dimengerti }\end{array}$ \\
\hline $\begin{array}{l}\text { Praktik public speaking di } \\
\text { dalam komunitas }\end{array}$ & $\begin{array}{l}\text { Peserta Language Center } \\
\text { Forum (LCF) }\end{array}$ & $\begin{array}{l}\text { Peserta memiliki rasa percaya } \\
\text { diri yang tinggi dan terlatih } \\
\text { menggunakan teknik public } \\
\text { speaking }\end{array}$ \\
\hline $\begin{array}{l}\text { Praktik public speaking di } \\
\text { lapangan (sekolah \&forum) }\end{array}$ & $\begin{array}{l}\text { Peserta Language Center } \\
\text { Forum (LCF) }\end{array}$ & $\begin{array}{l}\text { Peserta memiliki pengalaman } \\
\text { berbicara di tengah publik }\end{array}$ \\
\hline Evaluasi & $\begin{array}{l}\text { Peserta Language Center } \\
\text { Forum (LCF) }\end{array}$ & $\begin{array}{l}\text { Peserta menerapkan teknik } \\
\text { public speaking }\end{array}$ \\
\hline
\end{tabular}

4. Pendampingan Praktik Public Speaking di dalam Forum

Tahapan lanjutan setelah proses sosialisasi dilakukan adalah pendampingan praktik penerapan teknik public speaking di dalam lingkup forum. Kegiatan ini dilaksanakan oleh peserta forum dan dievaluasi oleh sesama peserta dan juga dosen pendamping. Sebagai bahan materi dan contoh sebelum praktik dilaksanakan, evaluasi singkat dengan menonton video pembicara dan teknik public speaking juga dilakukan terlebih dahulu. 
5. Monitoring Kemampuan Public Speaking dalam Metode Praktik di Masyarakat

Dalam kegiatan monitoring sebagai penutup atau kegiatan akhir dari kegiatan ini, tim akan mengevaluasi hasil akhir dari pendampingan dengan meminta peserta LCF berkonstribusi dalam event masyarakat, seperti contoh, sebagai pembicara dalam acara maulid Nabi, peringatan haul pesantren study tour ke lembaga kursus Madani Super Camp.

\section{HASIL DAN PEMBAHASAN \\ Hasil}

Pada pertemuan pertama, para peserta pendampingan secara terbuka membagikan suka duka mereka sebagai tutor. Mereka juga secara aktif bertanya dan merespon pertanyaan dan cerita yang dibagikan oleh para pembicara dan para peserta lainnya. Seluruh peserta juga turut membaca modul yang berisi materi public speaking. Bahkan, beberapa peserta juga berinisiatif untuk mencatat materi yang diberikan pada buku catatan mereka.

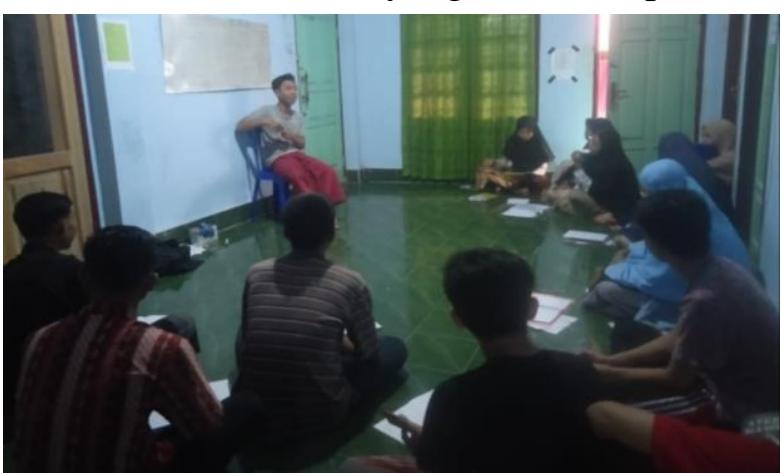

Gambar 1. Kondisi tutor lembaga kursus sebelum diberikan pendampingan

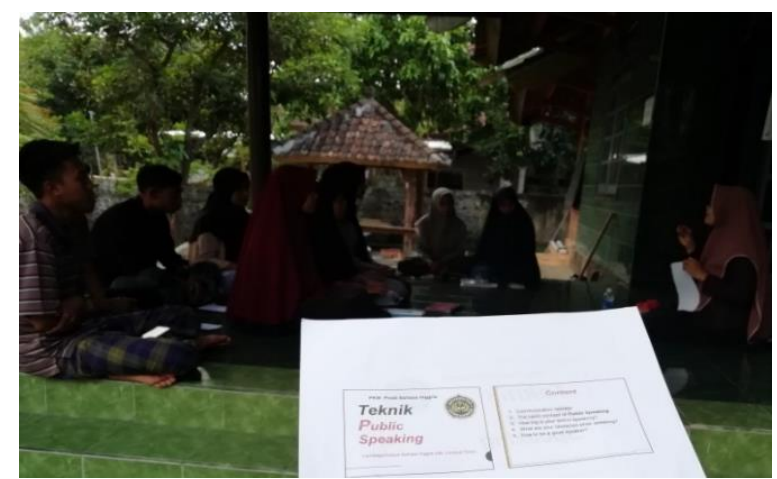

Gambar 2. Pendampingan pertama, Para tutor serius mendengarkan materi tentang public speaking

Pada pendampingan kedua, para tutor lembaga kursus diminta untuk mempraktikkan materi yang telah mereka dapatkan sebelumnya. Selain untuk melatih kemampuan public speaking para tutor, fungsi dari kegiatan ini adalah untuk melihat seberapa jauh materi yang telah dijelaskan dapat dipahami dan dipraktikkan oleh tutor. Pada kesempatan ini, para tutor terlihat antusias. Hal ini diindikasikan dari bagaimana mereka aktif mengomentari penampilan teman mereka. Selain itu para tutor yang sedang mempresentasikan materi public speaking juga tampak maksimal. Mereka mulai menggunakan alat bantu berupa polpen, melakukan interaksi dengan para tutor yang lain, menggunakan permainan, gesture dan kontak mata, dan lain-lain.

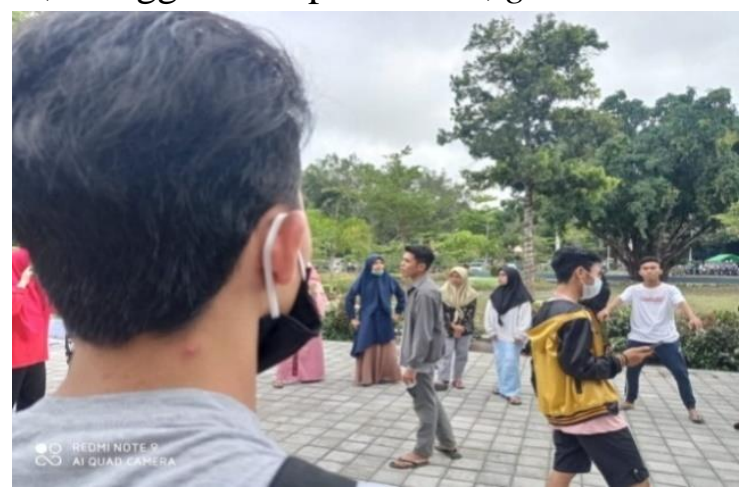

Gambar 3. Pendampingan kedua. Praktik public speaking di intern forum di taman Rinjani 
Selanjutnya, pada pendampingan ketiga, tidak dapat dipungkiri jika keaktifakan ini sempat menurun pada saat para peserta mengikuti studi banding ke lembaga kursus Madani Super Camp. Meski tidak ada satu orang pun dari 15 peserta pendampingan yang absen dalam studi banding ini, akan tetapi para peserta masih sulit untuk berbaur dan berperan aktif dalam diskusi. Hanya ada dua mahasiswa yang berani bertanya dalam sesi tanya jawab. Selebihnya, para peserta terlihat pasif, cenderung mengikuti arus diskusi dan segan untuk berbicara. kepasifan ini diakui muncul akibat kurangnya kesempatan untuk berbicara yang diberikan oleh pembina Madani Super Camp.

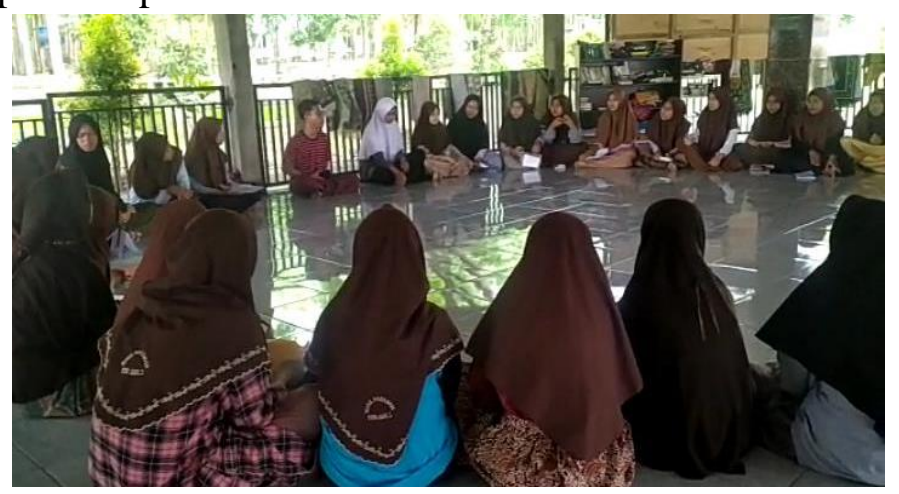

Gambar 4. Pendampingan keempat. Study tour ke Super Camp Madani

Untuk menindak lanjuti kondisi ini, para tutor kembali memberikan review terhadap kendala mereka selama di lapangan pada pendampingan keempat. Pada pembinaan kali ini, para tutor juga diminta menceritakan pengalaman mereka selama studi banding dan harapan mereka untuk kesempatan selanjutnya.
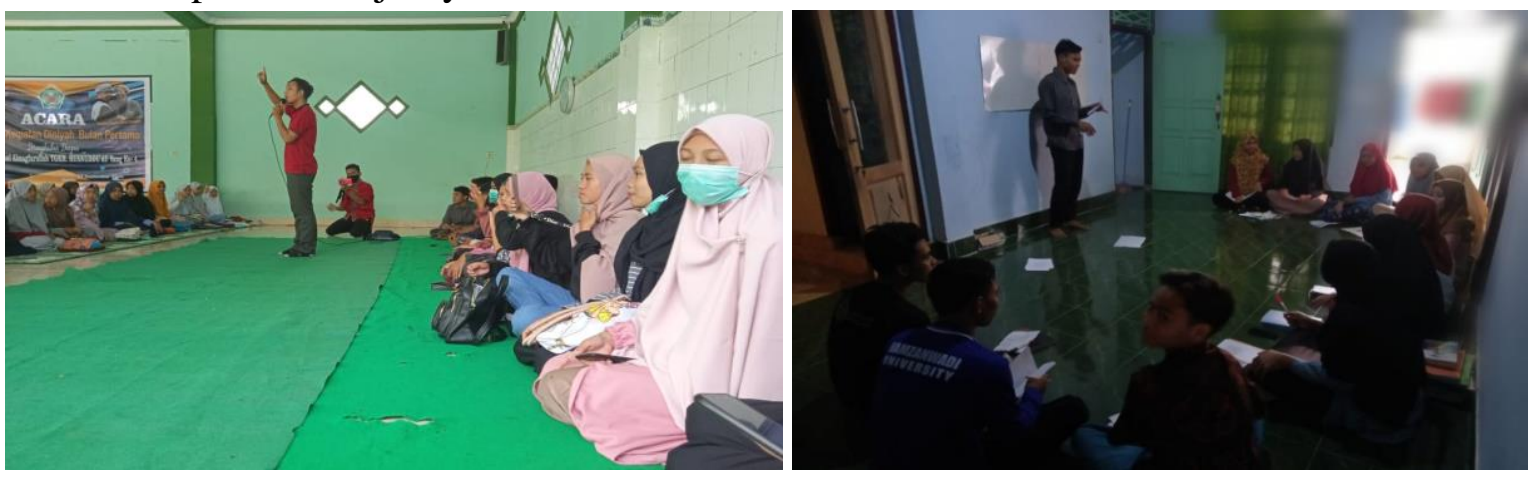

Gambar 5. Pendampingan kelima. Praktik public speaking di luar forum

Selain itu, untuk lebih mengetahui bagaimana feedback dari para tutor selama pembinaan public speaking, maka para 15 tutor diberikan angket singkat berupa 4 pertanyaan 4 likert-scales. Adapun hasil dari angket tersebut tergambar dalam grafik berikut: 


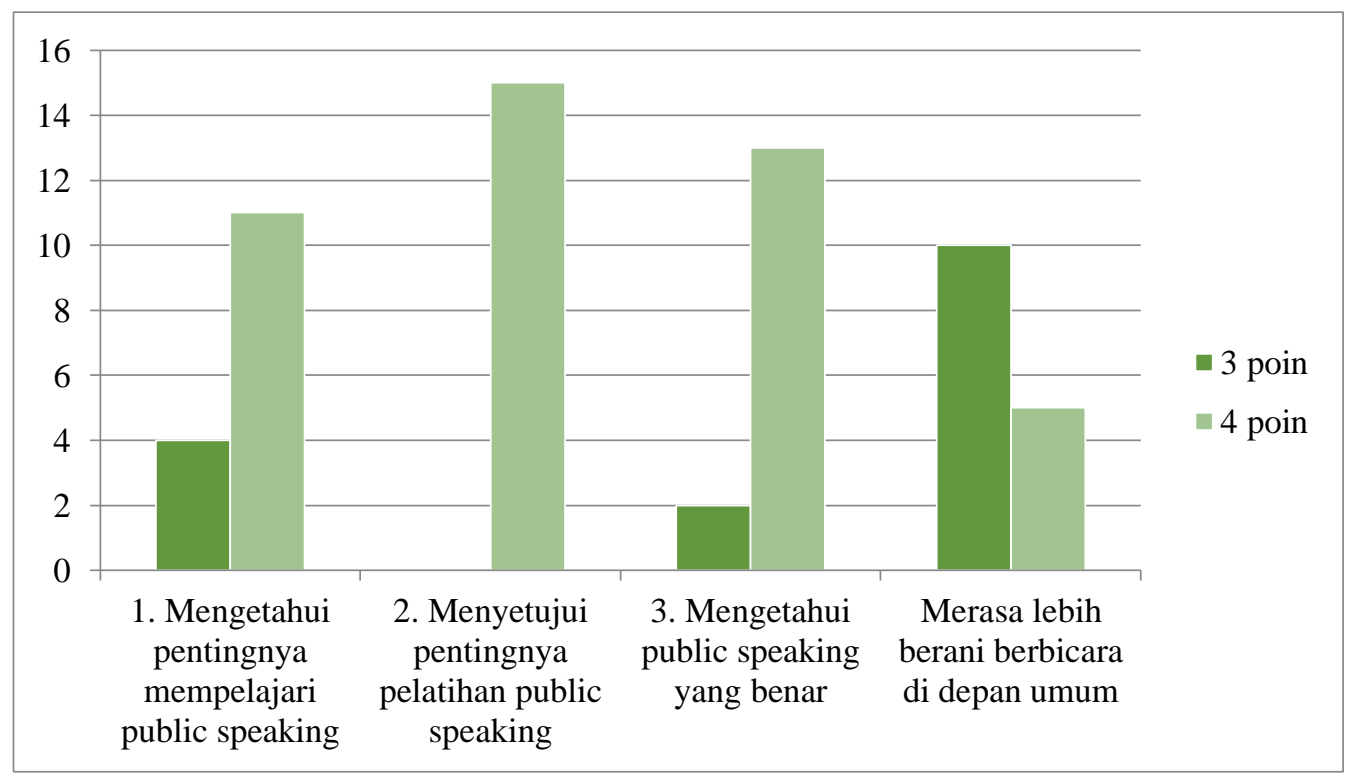

Grafik 1. Hasil angket peserta pendampingan teknik public speaking

Dari grafik di atas dijelaskan bahwa 11 orang mengetahui benar pentingnya mempelajari public speaking dan 4 orang lainnya cukup mengerti tentang hal ini. Jika di persentasekan, 93\% dari peserta pendampingan mengetahui fungsi dari public speaking ini. Bahkan $100 \%$ dari mereka setuju dan mengakui bahwa pendampingan public speaking ini penting bagi mereka. Selanjutnya, 13 peserta mengetahui teknik public speaking yang benar secara pasti, dan 2 orang mengaku jika mereka cukup mengetahui tentang public speaking yang benar. Artinya, 97\% mengetahui materi public speaking yang telah diajarkan. Namun, 5 peserta merasa sangat berani berbicara di depan publik dan 10 orang mengaku cukup siap jika berbicara di depan umum. Atau dengan kata lain, $83 \%$ dari para peserta siap jika diminta berbicara di depan umum.

Meski demikian, pada pendampingan kelima, kemampuan peserta terhadap penerapan public speaking benar-benar terlihat ketika para peserta diminta berbicara dalam komunitas mereka sendiri dan tanpa pengawasan pelatih secara langsung. Sebagai contoh, pada saat peserta diminta berbicara dengan sesama peserta pendampingan, berbicara di lokasi lembaga kursus peserta pendampingan sendiri dan di acara kegiatan kemasyarakatan. Teknik public speaking yang muncul adalah penggunaan alat bantu polpen, gesture, eye contact, interactive question, chuncking dan pausing technique, posisi berbicara berdiri, serta adanya permainan intonasi dan artikulasi ketika berbicara.

\section{PEMBAHASAN}

Dari hasil observasi dimana para tutor kursus terlihat serius mendengarkan materi dan juga darii hasil angket pada item 1 dan 2 tentang mengetahui dan menyadari akan pentingnya pendampingan public speaking, dapat disimpulkan jika pada awal pendampingan, para peserta merasa sangat antusias mengikuti pendampingan teknik public speaking ini. Pertanyaan yang muncul dari peserta setelah penyampaian materipun selaras dengan materi yang diberikan, yakni tentang teori dan isu tentang public speaking. Pengabdian memang seharusnya menyediakan teori-teori yang bersangkutan dengan bahan ajar yang akan dipelajari, sehingga peserta mampu mengetahui struktur public speaking yang mereka pelajari (Hakim, 2016). 
Selain bertanya, para peserta juga dengan terbuka mengaku bahwa mereka seringkali cemas dan ketakutan ketika diminta untuk berbicara di depan umum, terlebih jika berada di komunitas baru. Mereka seringkali berkeringat, sakit perut, terbata-bata dan lupa terhadap apa yang akan disampaikan. Kecemasan ini berkaitan erat dengan pikiran negatif yang terlebih dahulu di bentuk oleh para tutor kursus sebelum tampil berbicara. Seseorang yang selalu berpikir negatif maka akan merasa panik, khawatir, dan merasa terancam dengan sesuatu yang belum tentu terjadi (Kholisin, 2014).

Selain itu, kecemasan ini mengindikasikan bahwa para tutor masih memiliki keterampilan berkomunikasi yang rendah. Seperti pada studi Ririn, Asmidir, dan Marjohan (2013: 275) menunjukkan bahwa keterampilan komunikasi seseorang berkorelasi negatif dengan kecemasan berbicara di depan umum. Jadi, semakin tinggi keterampilan komunikasi maka semakin rendah kecemasan berbicara di depan umum. Sebaliknya, semakin rendah keterampilan komunikasinya maka semakin tinggi kecemasan berbicara di depan umum.

Lebih jauh lagi, dapat disimpulkan juga bahwa para peserta masih belum terbiasa dan belum siap untuk berbicara di depan umum. Hal ini dilihat dari bagaimana mereka kurang aktif berkontribusi dalam diskusi pada saat kegiatan studi banding. Padahal, pada saat itu mereka sudah mendapat materi dan pendampingan public speaking di intern forum atau di dalam lingkungan pendampingan. Hal ini memang kerap terjadi karena selain harus memiliki pemahaman yang baik tentang public speaking, para tutor juga perlu melakukan latihan yang intensif dan sejalan dengan tujuan para pembicara. Sama seperti yang disarankan oleh validator pada penelitian Hakim (2016) bahwa peneliti seharusnya menambahkan kegiatan yang memotivasi siswa untuklebih aktif dalam kegiatan public speaking. Untuk memindaklanjuti saran tersebut, tim PKM pun memberi prelatihan kepada para peserta untuk terjun langsung dan berbicara di dalam publik yang sejalan dengan profesi dan lingkungan mereka, yakni berbicara pada kelompok masyarakat dan lembaga kursus mereka sendiri.

Pada kegiatan praktik di lapangan, para peserta memiliki kewajiban untuk menyampaikan ilmu yang telah mereka dapatkan di pendampingan kepada para siswa mereka sendiri. Pada kesempatan ini, teknik public speaking pun muncul ketika mereka berbicara. Para tutor ini tidak hanya memaksimalkan kemampuan verbal atau kata-kata mereka saja, tetapi mereka juga mencoba berkomunikasi dengan non verbal layaknya pembicara handal. Sama seperti Najwa Syihab pada Setyawati \& Naryoso (2019), yang kerap menggunakan gerak isyarat, bahasa tubuh, ekspresi wajah, kontak mata, penggunaan berbagai simbol, serta cara berbicara seperti intoasi, penekanan, kualitas suara, dan gaya berbicara. nonverbal adalah proses komunikasi dimana pesan yang disampaikan tidak menggunakan kata-kata melainkan bisa dalam bentuk.

Selanjutnya, dari data angket kita bisa melihat bahwa pendampingan teknik public speaking ini memberikan efek positif yang signifikan terhadap perkembangan peserta pendampingan. Dari data tersebut, para peserta memberikan nilai 3-4 poin terhadap pemahaman dan kemampuan mereka terhadap teknik public speaking. Bahkan, mereka sadar benar terhadap pentingnya materi ini untuk profesionalitas mereka sebagai tutor pendidikan non formal. Walau demikian, para peserta ini secara berkesinambungan dan rutin perlu menempa diri untuk berbicara di depan umum demi meningkatkan kepercayaan diri dan keberanian mereka sendiri. Seperti yang disampaikan Hakim (2016), para calon pengajar perlu berlatih berbicara secara 
terus menerus untuk menyampaikan pesan lisan dengan sempurna dan bisa dipahami oleh pendengar dengan baik.

Jika dari hasil observasi dan angket, bisa dilihat bahwa tutor lembaga kursus yang ternaung dalam Foreign Language Center ini telah belajar dan berlatih banyak pada pendampingan teknik public speaking. Mereka telah mempraktikkan teknik gerak tubuh dan kontak matayang diajarkan pada pendampingan pada saat berbicara di depan publik, seperti saat mengajar di kursus mereka dan saat menjadi pembicara di depan masyarakat. Mereka juga lebih memperhatikan teknik artikulasi, notasi, teknik breaking dan pausing saat berbicara. hal yang tidak kalah penting adalah mereka telah siap jika nantinya diberikan kesempatan berbicara di depan umum. Jadi, bisa dikatakan bahwa lembaga tutor yang mereka pegang memiliki peningkatan dalam segi kualitas pengajarnya. Semakin baik lembaga kursus dan pendampingan dalam mencari materi kursus yang sesuai dengan kebutuhan peserta, menyediakan tutor yang berkompeten, dan menggunakan strategi mengajar yang efektif, maka lembaga kursus dan pendampingan dapat pembelajaran yang berkualitas (Wikanah, 2014).

\section{SIMPULAN}

Berdasarkan hasil pelaksanaan program pengabdian kepada masyarakat dapat disimpulkan bahwa kegiatan pendampingan teknik public speaking pada keterampilan berbicara para tutor lembaga kursus Bahasa Inggris di kec. Selong, kab. Lombok Timur berjalan dengan baik dan lancar. Hal ini diketahui dari tingkat kehadiran dan keaktifan para peserta dari awal sampai akhir pendampingan pada bulan Oktober. Para peserta yang hadir sangat antusias dalam mendengarkan penjelasan dan aktif bertanya terkait public speaking. Pendampingan ini juga meningkatkan pengalaman para tutor dalam berbicara pada publik sehingga ketampilan dan kualitas peserta pendampingan meningkat. Hasil dari kegiatan ini adalah diharapkan bagi peserta dapat menerapkan pengetahuan yang telah diperoleh dalam lembaga kursus yang mereka jalankan. Hal ini dapat mendukung terwujudnya program pemerintah dalam peningkatan

kualitas pendidikan non formal tingkat daerah kabupaten Lombok Timur khususnya dan pulau Lombok pada umumnya. Diperlukan adanya bantuan peningkatan sarana dan prasarana dari pemerintah dan masyarakat agar lembaga kursus Bahasa Inggris di kabupaten Lombok Timur lebih lebih diakui kualitasnya. Selain itu, pendampingan marketing dan promosi perlu diadakan agar lembaga kursus tersebut lebih dikenal oleh masyarakat luas.

\section{PERNYATAAN PENULIS}

Artikel pengabdian kepada masyarakat berjudul "Pendampingan Public Speaking pada Tutor Lembaga Kursus Bahasa Inggris di Kecamatan Selong, Kabupaten Lombok Timur” ini belum pernah dipublikasikan dalam jurnal ilmiah manapun.

\section{DAFTAR PUSTAKA}

Ahmad, M. (1990). Strategi BelajarMengajar Ketrampilan Berbahasadan Apresiasi Sastra. Malang: YA3.

Andriyanti, E. (2015). Lingkungan Otentik dan Beberapa Aspek Penting dalam Pembelajaran Public Speaking(Thesis). UNY, Yogyakarta. 
Surayya, S. A., Asrobi, M., \& Prasetyaningrum, A. (2020). Pendampingan public speaking pada tutor lembaga kursus bahasa Inggris. ABSYARA: Jurnal Pengabdian Pada Masyarakat, 1(2), 36-45. doi:10.29408/ab.v1i2.2724

Arsjad, M. G.\&Mukti U.S. (1988). Pembinaan Keterampilan BerbicaraBahasa Indonesia. Jakarta: Erlanga

Burhanudin, A. M. \& Syathori, A. (2019). Peningkatan Public Speaking Mahasiswa Jurusan KPI: Upaya Mencetak Da'i yang Rahmatallil 'Alamin. Orasi jurnal dakwah dan komunikasi., 10 (1), 1-21.

Hakim, MAR. (2016). Pengembangan materi bahan ajar public speaking berbasis communicative language teaching bagi mahasiswa di Indonesia. Manhaj. 4 (3). 229-237.

Kholisin (2014). Kecemasan berbicara ditinjau dari konsep diri dan kecerdasan emosional. Jurnal ilmu dakwah. 34(1). 77-102.

Munip, A. (2016). Model Public Speaking Kyai dalam Menanamkan Nilai-Nilai Pendidikan pada jamaah Majelis Doa dan Taklim At-Taqwa Wonokromo Pleret Bantul DIY. Cendikia jurnal kependidikan dan kemasyarakatan. 14(1).1-14. https://doi.org/10.211154/cendikia.vl4il.613

Maclntyr, P. D. (2007). Willingness to Communicate in the Second Language: Understanding the Decision to Speak as A Volitional Process. The modern language journal. 91 (4), $564-$ 576.

Nugrahani, D., Kustantinah, I., K, R. F. H., \& Larsati.(2019). Peningkatan Kemampuan Public Speaking melalui Metode Pendampingan Anggota Forum Komunikasi Remaja Islam(Unpublished research article). IKIP PGRI, Semarang.

Pratiwi, P. A. A.S.,Savitri, P. W., Qomariana, Y., \& Dewi, A. A. S. S. S.(2016). Pendampingan Public Speaking bagi Sekaa Teruna Satya Darma Kerthi Banjar Kaja Desa Sesetan (Laporan PKM). Universitas Udayana, Bali.

Putri, D. V. (2017). Lancar Pidato \& Public Speaking Tanpa Grogi, Tanpa Panik. Yogyakarta: Komunika.

Ririn, A. Marjohan, 2014, Hubungan Keterampilan Komunikasi dengan Berbicara di Depan Umum. Jurnal Ilmiah Konseling UNP, 2(1), 273-278.

Setyowati, Y. \& Naryoso, A. (2019). Analisis Kemampuan Public Speaking dan Komunikasi konvergensi Host pada Acara Talk Show Mata Najwa Metro TV. Interaksi Online. 7(4). 69-78

Sirait, B. C. (2008). The Power ofPublic Speaking: Kiat Sukses Berbicara di Depan Publik. Jakarta: Gramedia Pustaka Utama.

Syahroni, A. M. (2019). Pengaruh Program Pembiasaan terhadap Peningkatan Kualita sPublic Speaking Santri Pondok Pesantren Mambaus Sholihin Suci Manyar Gresik (Thesis). UIN Sunan Ampel, Surabaya. Retrieved from digilib.uinsby.ac.id.

Tarigan, H. G. (1998). BerbicaraSebagai Suatu Keterampilan Berbahasa. Bandung.

Wikanah, D. I. T. (2014). Pengelolaan Pembelajaran Berbasis Kualitas di Lembaga Kursus dan Pelatihan Magistra Utama Kota Semarang (Doctoral dissertation, Universitas Muhammadiyah Surakarta).

Yanti, R. (2017). Peningkatan Kemampuan Public Speaking melalui Metode Pendampingan Kader pada Organisasi ISKADA (Thesis). Universitas Islam negeri Ar-Ransry, Banda Aceh. 